\title{
The Corona-virus Pandemic in the Context of Reading and Interpreting the Signs of the Times Jana Maryšková
}

DOI: $10.32725 /$ cetv.2021.006

\begin{abstract}
:
The article discusses the current corona-virus pandemic as a possible 'sign of the times' in the sense of the Church's role in 'examining the signs of the time and interpreting them in the light of the gospel'. It also asks how the corona-virus pandemic can be interpreted in this context. First, it presents general criteria for reading the signs of the times. Then it gives four selected interpretations of the corona-virus pandemic which are then theologically reflected upon using the above criteria. Based on this reflection, it shows that not every interpretation of a pandemic can be considered a reading of the signs of the times. It thus points to the need to distinguish signs and the importance of the requirement 'to judge the Christian meaning of events with the help of the Holy Spirit and in the light of God's word'.
\end{abstract}

Keywords: corona-virus pandemic, signs of the times, theology of retribution, globalisation, solidarity

In the morning sermon in the chapel of the Saint Martha House on 23 ${ }^{\text {rd }}$ October 2015, shortly before the end of the second session of the Synod of Bishops on the Family, Pope Francis emphasised the fact that changing times required Christians to change along with them. Their 'attitudes must be constantly on the move in accordance with the signs of the times.' The Pope also mentioned that Christians must remain faithful to the 'truth of the gospel'. They should not adjust to the world, and fall into a 'comfortable conformism'. On the contrary, it is important to carefully distinguish between ongoing changes, without fear and in freedom. It is therefore necessary to open ourselves to the power of the Holy Spirit and try to understand well, through discernment, what is happening not only within us but also around us: '(...) our work is to look inside and discern our own feelings and thoughts. And also have a look at what is happening outside and the discernment of the signs of the times.' ${ }^{2}$ For, as the Pope points out, the reading and interpretation of the signs of the times is not an 'exclusive task of cultural elites'. Jesus does not speak in front of

1 @ PAPEŽ FRANTIŠEK, Die Zeiten ändern sich, L'Osservatore Romano 46/2015, German edition (online), available at: http://www. vatican.va/content/francesco/de/cotidie/2015/documents/papa-francesco-cotidie_20151023_zeiten-aendern-sich.html, cited $2^{\text {nd }}$ December 2020.

2 Ibid. 
academics, doctors, and intellectuals. His audience is ordinary peasants (cf. Matthew 16:2-3; Luke 12:54-55). Therefore, the task of all Christians is to try to recognise these signs and God's will 'in silence, reflection, and prayer.' ${ }^{3}$

Although the pope's words were spoken in the context of the ongoing Second Synod on the Family, they are not limited to marriage and the family. They are generally applicable, because 'the Church has always had the duty of scrutinizing the signs of the times and of interpreting them in the light of the Gospel. Thus, in language intelligible to each generation, she can respond to the perennial questions which men ask about this present life and the life to come, and about the relationship of the one to the other.' Therefore, the current corona-virus pandemic, which has severely affected many areas (the private, professional, and public lives of millions of people around the world, national economics, politics, culture, health care in individual states), has shown our vulnerability, and has called into question many certainties, may be understood as a sign of the times in the sense of the Pope's definition. However, the question is how Christians should read this sign of the times, what possible interpretations it offers, and in what sense the current corona-virus crisis can or cannot be considered a sign of the times. The presented article seeks to answer this question.

\section{Reading and Interpretation of the Signs of the Times}

Although the reading and interpretation of the signs of the times is a task for all Christians, as mentioned above and as recalled, for example, by the pastoral constitution Gaudium et spes, ${ }^{5}$ not every event can be considered a sign of the times and thus a distinction must be made: 'The People of God believes that it is led by the Lord's Spirit, Who fills the earth. Motivated by this faith, it labors to decipher authentic signs of God's presence and purpose in the happenings, needs and desires in which this People has a part along with other men of our age.' ${ }^{6}$ As M. Vogt emphasises, criteria are needed in the process of the interpretation of historical phenomena in the light of faith. It has to be distinguished from the compliance with the spirit of the times and cleansed of randomness and ideological coloration. Vogt offers the following criteria of the signs of the times inspired by Hünermann, Sander, and Ruggieri, without claiming completeness. ${ }^{7}$ ) 'Signs of the times' are phenomena that mark a certain epoch with their generality and frequency. They do not concern only individual groups and their interests, but humanity as a whole. They are of universal significance for the development and future of humanity. Theologically, they relate to the process of seeing traces of the future now and here. 2) 'Signs of the times' refer to the essential questions of human existence, in which the hardships and desires of a certain time are articulated. It is not a projection of a person's desire. These questions arise from the suffering, failure, and vulnerability in which the desire for God's saving action manifests itself sub contrario. 3) The 'signs of the times' are not events in history and nature as such. They are represented by the resulting changes in people's consciousness. These are changes in understanding, orientation, changes in measures caused by situations of emergency, which can turn into an experience of rescue, salvation. And finally 4) 'Signs of the times' refer to crises that require the person's decision. One must choose between the right or the wrong option. Thus, according to Vogt, the signs of the times are those 
crisis phenomena in which the possibility of a decision for God and for life appears. Similarly, the aforementioned H.-J. Sander sees the signs of the time in events which oblige one to decide whether to act humanly or inhumanly. In other words, he will protect human dignity or not. God identifies with those whose dignity is at stake and calls man to behave humanly and not inhumanly in events that suppress or destroy human dignity. Man should protect human dignity in order to be in accordance with God's will. ${ }^{8}$

$\mathrm{H}$. Waldenfels also presents a possible form of reading the signs of the times. He uses the example of the Instrumentum Laboris which was drafted by the Ordinary General Assembly of the Synod of Bishops in 2012. Its topic was the 'New Evangelisation', and it dealt with the analysis of the time in seven areas: cultural, social, economic, political, scientific-technical, communication, and religious. In the social field, for example, it was stated that the world is largely characterised by the phenomenon of migration. Thus, a 'climate of extreme migration' is emerging, which, however, leads to the creation of new forms of solidarity. In the economic field, the gap between rich and poor is widening, reinforcing violent tendencies. In the field of science and technology, the progress leads to exaggerated expectations. Science and technology are at risk of becoming new idols of the present, etc. According to Waldenfels, it is important that these events are read and seen as what they are: as a sign of ongoing changes. They are perceived in context. In their framework, the experience of the Church develops. Therefore, they must be received and purified in the process of discerning and confrontation with Christian faith. This enables a critical reading of the lifestyle, thinking, and expression of people of 'today's time', but also a critical reading of the current style of pastoral care or of the way of evangelisation of the Church. Thanks to this distinction, which, in this case was stimulated by the topic of new evangelisation, it turned out, for example, that traditional forms of evangelisation need profound changes and Instrumentum laboris formulates requirements for evangelisation today. ${ }^{9}$

The above examples show that the signs of the times can be found in everyday lives of people as well as in the life of the Church, and that 'the Church has always had the duty of scrutinizing the signs of the times and of interpreting them in the light of the Gospel. ${ }^{10}$ The Church must be able to distinguish non-changing elements from the changing ones that change along with the changes in the world; these examples further show that the signs of the times are not only events that characterise a certain time (as perceived by, for example, John XXIII ${ }^{11}$ ) but also events that call for interpretation, both by theologians and Christians in general. They should 'with the help of the Holy Spirit... hear, distinguish and interpret the many voices of our age, and to judge them in the light of the divine word. ${ }^{12}$ The examples also show that the reading of the signs of the times will never be a completed process. It remains a permanent task as long as the Church and the world exist.

\section{How Can One Read the Current Corona-virus Pandemic?}

Today, in the ongoing pandemic of corona-virus, a number of experts from the area of politics, economy, psychology, medicine, etc., make comments on this situation. Their opinions can be

8 Cf. Hans-Joachim SANDER, Theologischer Kommentar zur Pastoralkonstitution über die Kirche in der Welt von heute Gaudium et spes, in: Herders Theologischer Kommentar zum Zweiten Vatikanischen Konzil, volume 4, special edition, eds. Peter HÜNERMANN and Bernd Jochen HILBERATH, Freiburg - Basel - Wien: Herder, 2009, p. 725.

9 Cf. Hans WALDENFELS, Zeichen der Zeit, in: Die großen Metaphern des Zweiten Vatikanischen Konzils. Ihre Bedeutung für heute, ed. Mariano DELGADO and Michael SIEVERNICH, Freiburg - Basel - Wien: Herder, 2013, pp. 114-117.

10 Gaudium et spes, 4.

11 Cf. Pacem in terris, 39.

12 Gaudium et spes, 44. 
found daily in print and electronic media or on social networks. Some of these views are erudite; others, especially on social networks, can often be considered a projection of one's own wishes or a reflection of an individual's psychological characteristics (conspiracy theories, fake news, etc.). It is not always easy to navigate oneself in a flood of these, often conflicting, views. However, the corona crisis does not have political, economic, health, or social aspects only. It is - as a significant event characterising our time - a context for theological reflection. As mentioned above, it must be examined and interpreted in the light of the Gospel. ${ }^{13}$ Some possible interpretations of the corona-virus pandemic are given in the following paragraphs.

\section{Pandemic as a sign of God's punishment}

One possible way of reading the current corona-virus crisis is to interpret it as a sign of God's punishment for the sins of people who live etsi Deus non daretur, either in relation to other people or in relation to nature, as pointed out, for example, by L. Boff. According to Boff, the current corona-virus crisis is the result of people's irresponsible attitude towards our Earth, long-term indifference to ecological crises, climate change, ruthless plundering of natural resources, and loss of respect for nature. Boff refers to J. Lovelock who talks about the revenge of the Great Mother Earth in the form of typhoons, floods, droughts, diseases such as dengue fever, Zika virus, SARS, Ebola, or the current corona-virus. Boff does not share the vision of the retribution of Mother Earth, but appeals to a fundamental change in approach to our planet. ${ }^{14}$

Although, according to $\mathrm{H}$. Zaborowski, the corona-virus crisis is a symptom of the deep problems which we have been facing for many years (such as the loss of consciousness of unity and solidarity in modern societies, the economisation of health care, the effort to subordinate everything to the market and mathematical calculations, the inability of postmodern man to endure suffering and accept one's own mortality, the idolatrisation of scientific and technical progress, etc.) ${ }_{1}^{15}$ it cannot be considered God's punishment simply because it affects all people equally (including honest and just people, children, the poorest and most vulnerable whose side God chooses preferably). Moreover, given the millions of people on all continents affected by the corona-virus pandemic, no one is able to determine the specific sin which a person should be punished for. To interpret a corona-virus pandemic in this way would be like to stand in the position of God.

The understanding of sickness as a consequence of sin has no basis even in biblical texts - let us recall, for example, the book of Job, or when Jesus heals a man born blind. When the disciples ask Jesus the question 'Rabbi, who sinned, this man or his parents, that he was born blind?', he answers 'It was not that this man sinned, or his parents, but that the works of God might be displayed in him' (John 9:2-3). Similarly, in connection with another calamity, Jesus asks, 'Do you think that these Galileans were worse sinners than all the other Galileans, because they suffered in this way? No, I tell you; but unless you repent, you will all likewise perish. Or those eighteen on whom the tower in Siloam fell and killed them: do you think that they were worse offenders than all the others who lived in Jerusalem? No, I tell you; but unless you repent, you will all likewise perish' (Luke 13:1-5). So Jesus himself rejects this theology of retribution. The Lord does not want the

13 Ibid., 4

14 Cf. (c) Leonardo BOFF, As origens do Coronavirus, (online), available at: https://aterraeredonda.com.br/coronavirus-uma-reacao-erepresalia-de-gaia/, cited $3^{\text {rd }}$ December 2020.

15 Cf. Holger ZABOROWSKI, Über das Virus - unter Vorbehalt oder: Die Erschütterungen der Corona-Krise und die Möglichkeit der Solidarität, in: Christsein und die Corona-Krise: Das Leben bezeugen in einer sterblichen Welt. Mit einem Geleitwort von Papst Franziskus, ed. Walter Kardinal KASPER and George AUGUSTIN, 2 ${ }^{\text {nd }}$ ed., Ostfildern: Matthias Grünewald Verlag, 2020, pp. $105-106$. 
death of a sinner, He wants him to turn and live: 'Have I any pleasure in the death of the wicked, declares the Lord God, and not rather that he should turn from his way and live?' (Ezekiel 18:23), and similarly, 'Say to them, as I live, declares the Lord God, I have no pleasure in the death of the wicked, but that the wicked turn from his way and live (...)' (Ezekiel 33:11). The idea of a Creator who destroys his creation with pandemics runs counter to the belief in a merciful God who offers a sinful and imperfect person the possibility of forgiveness (cf. Genesis 18:23-33). The mercy of the Lord triumphs over judgment (cf. James 2:13).

The corona-virus pandemic should therefore not be read as a sign of God's retribution; God does not send the virus to mankind as punishment for its sins. If the Scriptures nevertheless speak of God's punishment, then, according to Cardinal Koch, it is in the sense of letting man bear the consequences of his or her own actions committed freely. People thus punish themselves if they disobey God's commandments. Therefore, they are called to conversion. In this sense, the current corona-virus crisis not a question asking: 'WHY does God let this pandemic happen?' It is rather a question wandering: 'WHAT does God want to tell us with this crisis and what should Christians (not only) learn from it in the future?'16 It should not, therefore, lead to a resigned attitude with reference to God's unchangeable will. On the contrary, it should lead to an active way of Christian life. One should help those who are affected by the corona-virus crisis the most, because an active life derived from the gift of faith, from the Gospel, a life for others, is the main task of Christians today.

\section{Pandemics as a sign of 'bad' globalisation}

Globalisation can be considered a key context of our time. It is a transformation process that has many dimensions and thanks to which humanity is increasingly interconnected in many areas today. We are talking about the globalisation of the economy, financial markets, interconnection with communication technologies; however, this process also includes social exclusion or an increase in the number of poor people. As Pope Benedict XVI states:

The processes of globalization, suitably understood and directed, open up the unprecedented possibility of large-scale redistribution of wealth on a world-wide scale; if badly directed, however, they can lead to an increase in poverty and inequality, and could even trigger a global crisis. It is necessary to correct the malfunctions, some of them serious, that cause new divisions between peoples and within peoples, and also to ensure that the redistribution of wealth does not come about through the redistribution or increase of poverty... ${ }^{17}$

It is the negative phenomena and risks associated with globalisation that are the subject of its criticism and reflections upon the end of globalisation. For critics of globalisation, the current corona-virus pandemic is a confirmation of their attitudes. ${ }^{18}$ However, according to Benedict XVI, 'Globalization is a multifaceted and complex phenomenon which must be grasped in the diversity and unity of all its different dimensions, including the theological dimension. In this way it will be possible to experience and to steer the globalization of humanity in relational terms, in terms of

16 Cf. Kurt Kardinal KOCH, Die Corona-Krise mit den Augen des Glaubens betrachten, in: Christsein und die Corona-Krise: Das Leben bezeugen in einer sterblichen Welt. Mit einem Geleitwort von Papst Franziskus, ed. Walter Kardinal KASPER and George AUGUSTIN, $2^{\text {nd }}$ ed., Ostfildern: Matthias Grünewald Verlag, 2020, p. 34.

17 Caritas in veritate, 42.

18 Cf. ZABOROWSKI, Über das Virus..., p. 110. 
communion and the sharing of goods.'19 And as Pope John Paul II states, 'Globalization, a priori, is neither good nor bad. It will be what people make of it.'20

Globalisation certainly has a number of problematic aspects, including the current corona-virus pandemic. The impact of the illness is felt in virtually every area of life by people around the world - the 'global vulnerability of the global world' is showing itself. ${ }^{21}$ However, the corona-virus pandemic cannot be seen as a sign of 'bad' globalisation which could be then unilaterally reduced to negative aspects only. According to $\mathrm{H}$. Zaborowski, there is another globalisation, of which its roots can be found in Christianity, among others, and which was further developed in modern times - in the form of the knowledge that we humans share a common world and form one community. This globalisation, which Zaborowski calls the globalisation of solidarity, is linked to a dual responsibility: social responsibility towards other people and ecological responsibility towards nature. The injustices and sufferings in one area or another, wherever they take place in the world, must not be treated with indifference. ${ }^{22}$ According to Zaborowski, it cannot be ruled out that the corona-virus crisis will exacerbate existing inequalities. It means that northern states, for example, will cope better than southern states with it, the West will suffer less than eastern countries. It also means that differences might be deepened within individual societies: the rich, the educated, the healthy will have a better chance of going through the crisis unscathed than those who were already poor, the uneducated, and the sick before the pandemic. This is why people need solidarity with each other and solidarity with nature if the whole of humanity wants to survive on this planet. For this reason, according to Zaborowski, the $21^{\text {st }}$ century should be a century of solidarity emphasising the protection of human dignity. ${ }^{23}$ Pope Francis speaks similarly. According to him, an increasingly globalised society makes us neighbours, but not sisters and brothers. The Covid pandemic has shown our inability to act together. ${ }^{24}$ At the same time, however, 'this crisis has shown that it is crisis situations in which we depend on the solidarity of others. It encourages us to put our lives at the service of others. We should be shocked by global injustice so that we can wake up and hear the cries of the poor and our seriously ill planet.' ${ }^{25}$

So the sign of the times is not a corona-virus crisis as a global pandemic which can be observed since the outbreak of the first wave of the pandemic; it is the growing global solidarity based on the ability to be affected by the needs of another person, to commit oneself to others regardless of one's own interests, to be willing to risk one's own life for another person and his dignity (in homes for the elderly, hospitals, research laboratories, families, ${ }^{26}$ or in the most affected areas across national borders). As mentioned above, it is the decision to live and to protect human dignity. We are called by God, who identifies with those whose dignity is at stake, to act this way. In this sense, the corona-virus pandemic can be read as a sign - a sign of the globalisation of solidarity (as Zaborowski speaks of it). It is the task of the churches and all Christians to participate in shaping the humane dimension of globalisation and to bring values such as the dignity of every human person, justice, solidarity, and help to the poorest in society. This is needed especially in

19 Caritas in veritate, 42.

20 JAN PAVEL II., Promluva k Papežské akademii sociálních věd (27 ${ }^{\text {th }}$ April 2001), in: Insegnamenti XXIV, 1 (2001), Vatikán: Libreria Editrice Vaticana, 2003, p. 800.

21 (c) Tomáš HALÍK, Křestanství v čase nemoci, (online), available at: http://halik.cz/cs/tvorba/clanky-eseje/clanek/606/, cited $8^{\text {th }}$ December 2020.

22 Cf. ZABOROWSKI, Über das Virus..., p. 110.

23 Cf. ibid., pp. 110-111.

24 Cf. Fratelli tutti, 12.

25 FRANTIŠEK, Předmluva, in: Christsein und die Corona-Krise: Das Leben bezeugen in einer sterblichen Welt. Mit einem Geleitwort von Papst Franziskus, ed. Walter Kardinal KASPER and George AUGUSTIN, $2^{\text {nd }}$ ed., Ostfildern: Matthias Grünewald Verlag, 2020 , p. 6.

26 Cf. ZABOROWSKI, Über das Virus..., pp. 111-112. 
times of global threat which our world is facing and probably will face in the future. Solidarity is 'a firm and persevering determination to commit oneself to the common good; that is to say to the good of all and of each individual, because we are all really responsible for all. ${ }^{27}$

\section{A pandemic as a question of Christian identity}

Cardinal Koch describes a period of crisis, including the current corona-virus pandemic, as an hour of truth that will show our priorities not only in our human lives but also in our lives of faith. ${ }^{28}$ The pandemic, which emptied and closed churches during its first wave at the time of the most important Christian holidays, became an opportunity for Christians to reflect again and more deeply on their relationship with God and their Christian identity. As T. Halík states: 'The absence of public services was an opportunity to "go deep" and ask very important questions. If Sunday's visit to Mass was one of the main pillars of Christian identity for many Catholics, they had to face a question: What could be another and deeper source of one's life of faith? What makes one a Christian when traditional "church traffic" suddenly stops working?' ${ }^{29}$ At the same time, "the time of empty churches' was an opportunity to reflect on the future of the Church: 'Perhaps this time of empty churches symbolically shows their hidden emptiness and possible future, unless they seriously try to introduce a completely different form of Christianity to the world. ${ }^{30}$

In this connection, Halík refers, among other things, to a quote by Pope Francis which was inspired by the book of Revelation: '...we need to open the door of our hearts to Jesus, who stands and knocks'. He also refers to the Pope's addition to this statement: 'Sometimes I wonder, though, if perhaps Jesus is already inside us and knocking on the door for us to let him escape from our stale self-centredness.' ${ }^{31}$ The time of closed churches is an opportunity for this 'going out' which the pope calls for - it is necessary to 'come out of churches and parishes, go out and look for people in places where they live, where they experience their sufferings and hopes. ${ }^{32}$ The picture describing such a church is a field hospital: 'It is quite clear to me that what the Church needs most of all today is the ability to heal wounds and warm human hearts. It needs closeness and solidarity. I see the Church as a field hospital after the battle. We do not have to ask the severely injured how high his cholesterol or sugar is. Wounds need to be treated. Then can we talk about everything else. ${ }^{33}$ It is therefore important for Pope Francis to 'turn from moralising Christianity to therapeutic Christianity. ${ }^{34} \mathrm{He}$ demands a Church where 'She does not wait for the wounded to knock on her doors, she looks for them on the streets, she gathers them in, she embraces them, she takes care of them, she makes them feel loved. ${ }^{35}$ The Church should not be a punishing church. It should allow reunion with the love which is God's mercy. This also applies to those who have not yet found their way to the Church or for some reason have left the Church: 'Instead of being just a Church that welcomes and receives by keeping the doors open, let us try also to be a Church that finds new roads, that is able to step outside itself and go to those who do not attend Mass, to those who have quit or are indifferent. ${ }^{36}$ Like Pope Francis, Cardinal Kasper says that the Church

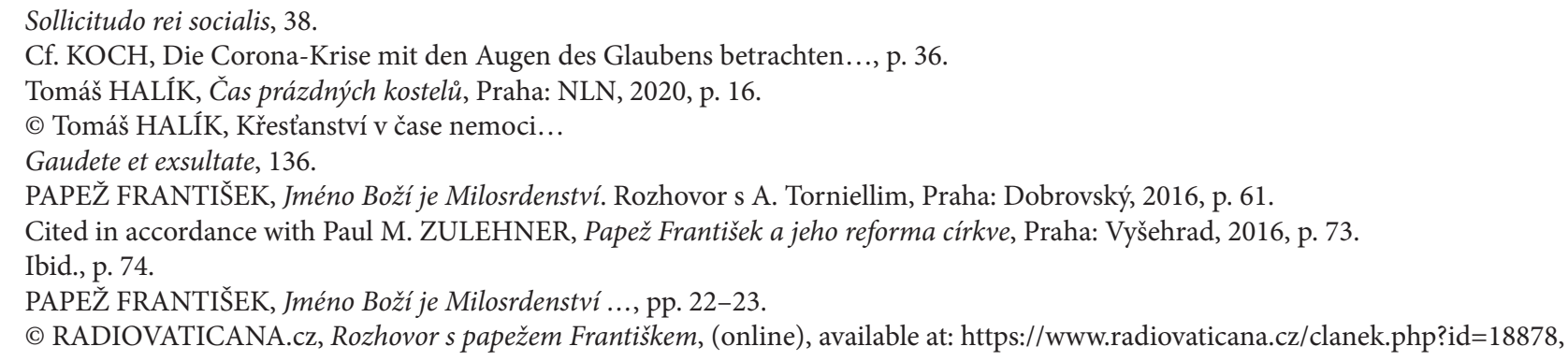


must be present in the world and must be a Church for others. Its future is a return to diakonia in the sense of Pope Francis' words about the Church as a field hospital. ${ }^{37}$

The time of closed churches during the ongoing corona-virus pandemic can therefore be read as a sign of how to better understand the Church's diaconal task. It should be truly the Church of Jesus Christ whose practice of favouring the poor, the sick, the excluded, as well as love towards the suffering and towards the neighbour in need, is a fundamental measure for Church practice. Also, this pandemic brings a question: What forms of pastoral activity should be chosen to suit the conditions of life of today's man and to be accepted by man today? Pastoral care of the future will no longer be able to be just providing pastoral care which merely gathers Christians. Not only communio, but also missio is important - mission, stepping out of one's structures, as Pope Francis repeatedly speaks about it. It is an active life from the Gospel, from the gift of faith for others. Christians should serve others, because support and help to others are seen as primary tasks of Christians today, as mentioned above. As T. Halík states:

Perhaps we should accept the present fast, i.e., the absence of worship and church service, as kairos, a time of opportunity to stop and to think carefully when facing God and with God. I am convinced that the time has come to think about how to continue this path of reform that Pope Francis is talking about: not attempts to return to a world that is no more, nor reliance on mere external reforms of structures, but a turn to the core of the gospel, 'the path into the deep. ${ }^{38}$

Let us add that this turn to the core of the gospel means mercy, solidarity in love, responsibility for the needy and excluded. Following the example of Jesus Christ, who 'emptied himself, by taking the form of a servant, being born in the likeness of men' (Philippians 2:7), the Church is to give up its closeness, to become 'one of the people', without losing her Christian identity based on the aspect of kenosis.

\section{A pandemic as a sign of God's appeal 'Make a neighbor of yourself!'}

The ongoing covid pandemic can be read in a variety of ways. One of the possibilities is to perceive it as a sign of God's punishment, as mentioned above, that is, as a question directed from man to God - 'why, for what sins', etc. However, the pandemic can also be read the other way round - as God's appeal to man. The Lord asks Adam: 'Where are you?' (Genesis 3:9). He then asks Cain: 'Where is Abel your brother?' (Genesis 4:9). Similarly, in the New Testament, Jesus tells a lawyer, 'You go, and do likewise' (Luke 10:37). All of these questions or appeals call for answers and can be read as questions for us in the current corona-virus crisis - Where is the place of us Christians in the time of the pandemic? Who is our neighbour? Are we neighbours to each other?

According to H. Steinkamp, to be one's neighbours is not to look at others from the perspective of seemingly healthy, strong ones. This can lead to distance. One is in danger of becoming stuck in the position of those who know best regarding what others need. In this way, neighbours become objects of diakonia. To be one's neighbour means to be struck by the other person's situation. Awareness of co-affliction (Mit-Betroffenheit) does not lead to non-participatory compassion and

cited $8^{\text {th }}$ December 2020.

37 Cf. Walter Kardinal KASPER, Corona-Virus als Unterbrechung - Abbruch und Aufbruch, in: Christsein und die Corona-Krise: Das Leben bezeugen in einer sterblichen Welt. Mit einem Geleitwort von Papst Franziskus, ed. Walter Kardinal KASPER and George AUGUSTIN, $2^{\text {nd }}$ ed., Ostfildern: Matthias Grünewald Verlag, 2020, p. 26.

38

(c) Tomáš HALÍK, Křestanství v čase nemoci... 
isolation of 'the others', but to identification with them, to a joint effort to improve their living situation. Thus, this approach protects the dignity of the other. The objects of diakonia become its subjects. Solidarity as a mutual diakonia for each other then means the complementarity of taking and giving, blurring the boundaries between the healthy and the sick, the strong and the weak. According to H. Steinkamp, this diakonia is listening to the crying of a neighbour. ${ }^{39}$ Similarly, P. Ambros states that

the decisive factor for diakonia is not the object of love, but the subject of love. Diakonia does not ask 'who my neighbour is', but (...) - with reference to the parable of the Good Samaritan - it asks 'What am I for my neighbour?' In diakonia, the meaning of help to one's neighbour changes: the question of one's identity is viewed through the prism of what a person in need is in the eyes of God. Every person who awakens the compassion of God becomes a neighbour. Through God's compassion the Christian is guided by the commandment: 'You go, and do likewise!' (Luke 10:37). ${ }^{40}$

The ability to be struck by the need of another person was demonstrated by all those who sewed masks during the first wave of the pandemic, provided shopping for seniors and people who fell ill with covid, helped as volunteers at hygiene stations with tracing, or talked over telephone lines with lonely seniors, etc. All of these people have heard the 'call of neighbour'. Instead of the path of 'inaction and waiting (in a resigned attitude that feeds on our need for security and follows a kind of "alternative logic": we are thinking of adapting to the current uncomfortable state and we want to do what we did before without violating restrictive regulations) ${ }^{34}{ }^{31}$ they have chosen the second path. This, 'on the contrary, lies in accepting this time and in active cultivating of a living relationship with Christ by creative finding of people who are particularly in need of our help.42 In this sense, the current corona-virus pandemic can be a sign for us Christians - a sign of God's appeal to become neighbours in relation to 'the others' and thus become disciples of Christ and that we do not cease to seek God in dialogue with others - not only with Christians, but also with agnostics and atheists. We should live in solidarity with our non-Christian environment, just as Jesus Christ came here with the feeling of solidarity with a sinful and suffering person. We should discover Christ in those whom we serve, precisely by serving them. ${ }^{43}$ We should, not only during the corona-virus pandemic, be the answer to 'the joys, hopes, sorrows and anxieties of the people of our time, especially those who are suffering. This can be a sign of God's appeal.

However, there is another important aspect in the appeal 'Make yourself a good neighbor?' M.-D. Chénu and H.-J. Sander marked as a sign of the time situations in history which were related to Jesus Christ. In other words, some everyday events can create conditions and space for the relationship between God and man, can be a preparation for man's encounter with God, and, as such, they are a sign of the times. ${ }^{44}$ Such events are situations where people in their everyday life strive for good. They recognise these situations in their conscience ${ }^{45}$ when they make the basic decision. As understood by V. Boublík, especially in relation to non-Christian religions (but how it can be understood in connection with human activities in the world), they choose the path

39 Cf. Jana MARYŠKOVÁ, Vybrané kontexty současné teologie: teologie křestanské praxe ve světě, Studia theologica 3/2016, pp. 94-95.

40 Pavel AMBROS, Doprovázet, rozlišovat, integrovat. Uvedení do pastorální antropologie, Olomouc: Refugium Velehrad-Roma, s.r.o., 2016, p. 240.

41 C M. CZERNY, 'Jak s Františkem číst znamení doby?', RadioVaticana.cz (online), available at, cited 11 $1^{\text {th }}$ December 2020.

42 Ibid.

43 Cf. Tomáš HALÍK, Divadlo pro anděly: Život jako náboženský experiment, Praha: NLN, 2010, p. 137; pp. 148-150.

44 Cf. Michal OPATRNÝ, Sociální práce a teologie: Inspirace a podněty sociální práce pro teologii, Praha: Vyšehrad, 2013 , p. 273.

45 Cf. Gaudium et spes, 16. 
that prepares and awaits salvation, ${ }^{46}$ because Any-one who sets off on the path of doing good to others is already drawing near to God, is already sustained by his help, for it is characteristic of the divine light to brighten our eyes whenever we walk towards the fullness of love. ${ }^{37}$ All those who, though non-Christians, heard the appeal 'Make yourself a good neighbor!' in their conscience and followed it (in the form of helping all those who were and are affected by the corona-virus during the pandemic), made this fundamental decision and chose good. For Christians, they are a sign showing that even "the radically humane" work of a non-Christian may have the quality of Christian diakonia, and that events in everyday life, or rather everyday life itself, may have an "eschatological depth", i.e., it may relate to things which transcend man.48

\section{Conclusion}

Since the Second Vatican Council (when the Church ceased to understand itself as societas perfecta, and opened itself to the world and entered into a dialogue with it), the problems of people in various life situations and serious topics for dialogue between the Church and the world have become the subject of theological reflection. The Church not only provides help to the world, ${ }^{49}$ but also receives help and inspiration from today's world, ${ }^{50}$ by reading the signs of the times. Therefore, all of God's people must ' (...) hear, distinguish and interpret the many voices of our age (...)..$^{51}$ The current corona-virus pandemic - as a significant event characterising our time today - wants to be read as a sign of the times. The article, without claiming completeness, presents four possible ways of reading and interpreting this pandemic and reflects them theologically. Based on this reflection, it shows which of these interpretations can be and which, on the contrary, cannot be considered a sign of the times. It also shows the sense in which a corona-virus pandemic can be understood as a sign of the times.

\section{Contact}

\section{Dr Jana Maryšková}

University of South Bohemia in České Budějovice

Faculty of Theology

Department of Social and Charity Work

Kněžská 8, 37001 České Budějovice

marysj00@tf.jcu.cz

46 Cf. OPATRNÝ, Sociální práce a teologie..., pp. 45-46

47 Lumen fidei, article 35.

48 OPATRNÝ, Sociální práce a teologie..., p. 46; p. 274.

49 Cf. Gaudium et spes, 41-43.

50 Cf. ibid., 44.

51 Ibid. 